pasient». Men Skapar vården ohälsa? kan anbefales. Den er særs aktuell, nå som staten gjennom samhandlingsreformen ønsker å satse mer på forebyggende medisin.

\section{Hasse Melbye}

Allmennmedisinsk forskningsenhet

Universitetet i Tromsø

\section{En grunnbok i endokrinkirurgi}

Lennard TW, red.

Endocrine surgery

A companion to specialist surgical practice.

4. utg. 231 s, tab, ill. Philadelphia, PA: Saunders

Elsevier, 2009. Pris USD 128

ISBN 978-0-7020-3016-1

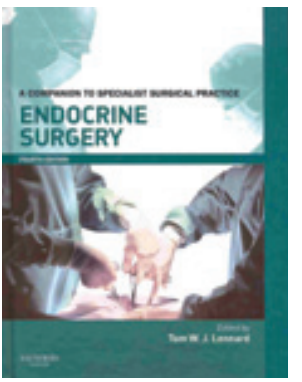

Boken er en del av serien Companion to specialist surgical practice. Denne er beregnet på leger under utdanning i kirurgi eller som er ferdige spesialister som ønsker kunnskapsbasert infor-

masjon på subspesialistnivå. Serien er også tilgjengelig i elektronisk bibliotek.

Endocrine surgery, som utkom første gang i 1997 og forrige gang ble revidert i 2005, har kapitler om parathyreoidea, thyreoidea, spyttkjertler, binyrer, arvelig endokrine sykdommer, endokrine pancreassvulster og gastrointestinale nevroendokrine tumorer. Bidragsyterne er britiske, svenske, franske og amerikanske. Boken er velredigert og har tekstinndeling i avsnitt med overskrifter som gjør det lett å finne det emnet man søker. Indekslisten er rikholdig og er en god veiviser ved detaljerte søk. Figurer og tabeller er stort sett av god kvalitet, opplysende og relevante. Hvert kapittel avsluttes med en liste over det forfatterne anser som hovedpunkter (key points). Referanselistene er fyldige. Referanser til arbeider som er av en slik kvalitet at de blir sterkt anbefalt, er merket $i$ teksten og i referanselisten med et eget symbol. Publikasjoner som gir grunnlag for meninger på et lavere kunnskapsgrunnlagsnivå (såkalte ekspertuttalelser) er merket med et annet symbol. Flere arbeider har også en kommentar om innhold og grad av kunnskapsgrunnlag. At den viser endokrinkirurgiens vitenskapelige fundament og også dens uløste oppgaver, gir den god verdi som lærebok. Tekst og referanselister er godt ajourført frem til tidlig 2008.

Boken inneholder også et meget leseverdig kapittel kalt «Clinical governance, audit and medico-legal aspects of endocrine surgery», der blant annet indikasjonsvurdering for kirurgi, klagesaker, kvalitetskontroll og subspesialisering problematiseres på en måte som har relevans utover det endokrinkirurgiske fagfeltet.

Innføringen i og oversikten over endokrinkirurgi er utmerket og gir bakgrunn for utredning, behandling og oppfølging av pasienter. Den inneholder mer informasjon enn man forventer ved en bok på bare 231 sider, men er ikke lærebok i kirurgisk teknikk.

Papir og trykk har god kvalitet, og pris og størrelse er ikke avskrekkende. Avdelinger med endokrinkirurgi som arbeidsfelt vil også ha glede av boken, bl.a. som bakgrunn for undervisningsopplegg. I så fall bør man i tillegg ha en av de større lærebøkene på fagområdet $(1,2)$.

Endocrine surgery anbefales varmt til leger som er spesialister i eller er under utdanning i generell kirurgi eller i subspesialiteten bryst- og endokrinkirurgi. Lennard og medarbeidere har laget en pedagogisk fremragende liten lærebok.

\section{Jan Erik Varhaug}

Avdeling for bryst- og endokrinkirurgi

Haukeland universitetssykehus

\section{Litteratur}

1. Clark OH, Duh Q-Y, Kebebew E, red. Textbook of endocrine surgery. Oxford: Elsevier Health Science, 2005

2. Randolph GW, red. Surgery of the thyroid and parathyroid glands. Philadelphia, PA: Elsevier Science, 2003

\section{Kjernepensum i generell kirurgi og akuttkirurgi}

Paterson-Brown S, red.

Core topics in general and emergency surgery

A companion to specialist surgical practice.

4. utg. 365 s, tab, ill. Philadelphia, PA: Saunders Elsevier, 2009. Pris USD 128

ISBN 978-0-7020-3017-8

Dette er fjerde utgaven av et bind som er relativt godt kjent blant kirurger. De første utgavene kom i 1995, og alle fire er redigert av denne bokens redaktør samt O. James Garden - begge med arbeidssted ved Royal Infirmary i Edinburgh, Skottland. Denne boken er den første i serien på totalt åtte bøker - flere av disse er anmeldt nå i Tidsskriftet. Bøkenes felles formål er å være ledsagende kompendier (ikke massive oppslagsverk) til praktiserende kirurger. De har korte kapitler som dekker dagens viten og grad av kunnskapsgrunnlag (eller mangel på dette) for å treffe fornuftige kliniske slutninger.

Denne første boken starter derfor med kapitler som introduserer leseren for kunnskapsbasert praksis i kirurgien, der grunn- laget for litteraturvalg, studiers styrker og svakheter samt bevishierarkiet beskrives. Det er noe tungvint at flere slike «bevisnivåer» fremlegges og at man på side 14 definerer hva som er nivå «I, II og III» i denne og de sju andre bøkene: Kjøper man for eksempel bare boken som omhandler transplantasjon eller karkirurgi, mister man den informasjonen. Dette valget av gradering gjengis dog $\mathrm{i}$ et énsides format $\mathrm{i}$ de andre bøkene, og oppleves som fornuftig.

Som kjernetema betegnes også et kapittel dedikert til helseøkonomiske spørsmål og utfall. Dagkirurgi, vurdering av den kirurgiske pasient, kirurgisk risiko, ernæring, perioperativ og intensiv behandling er temaer som forekommer spredt, blandet med kapitler om hernier, perforasjoner i øvre abdomen, akutte tilstander i tynntarm og appendix samt i lever-galle-pancreasog anorektalområdet. Abdominal sepsis beskrives sammen med abdominal kompartmentsyndrom, og buktraume for seg $i$ et eget kapittel. Både her og ved enkelte kapitler i de andre bøkene forekommer det en del overlappinger. Særlig gjelder det de gastrointestinale temaene. Men ved å gjøre det slik, kan man kjøpe hver bok for seg.

Hvert kapittel inneholder rikelig med referanser, der de viktigste studiene er markert og kommentert. Et knippe med 8-12 hovedpoenger oppsummerer hvert tema, og en rekke av kapitlene inneholder lenker til nettsteder. Språket er lett og ledig, og teksten rikelig avbrutt av tabeller, illustrasjoner og faktabokser i ulike fargetoner. Med hovedforfattertyngden fra det britiske øyriket er det ikke rart at de fleste tall og helserelaterte kostnadsberegninger er mest aktuelt for Storbritannia, men ellers er stoffet allmengyldig på langt de fleste områder.

Boken synes å egne seg vel så gjerne for kirurgiske kandidater som etablerte kirurger, og kan anbefales.

Kjetil Søreide

Kirurgisk avdeling

Stavanger universitetssjukehus

\section{Kjernepensum i lever-, galle- og pancreaskirurgi}

Garden OJ, red.

Hepatobiliary and pancreatic surgery

A companion to specialist surgical practice. 4. utg. 361 s, tab, ill. Philadelphia, PA: Saunders Elsevier, 2009. Pris USD 128

ISBN 978-0-7020-3014-7

Fjerde utgave av denne boken, som først ble utgitt i 1997, er oppdatert med kapitler som omtaler leverfunksjon og leversvikt, ikkekolorektale levermetastaser og pancreass- 
vulster utenom adenokarsinom. O. James Garden fra Edinburgh, Skottland har redigert denne boken og er også redaktør for hele bokserien. Formatet er som i resten av serien, og innholdet er balansert med graderte råd basert på best tilgjengelig kunnskapsgrunnlag, som beskrevet i Core topics in general and emergency surgery. Redaktøren erkjenner den økende bruken av multidisiplinære team i behandlingen av komplekse problemstillinger samt at de kirurgiske grensene og indikasjonene flyttes fortløpende og at ikke alle dyptpløyende deler av temaene kan dekkes.

De første kapitlene omhandler fysiologiske og anatomiske aspekter samt laparoskopiens rolle ved stadiebestemmelse og diagnostisering av malign sykdom. Deretter omtales fortløpende diverse benigne og maligne tilstander i lever-, galle- og pancreasområdet samt traumer.

Som i de andre bøkene har hvert kapittel rikelig med referanser, der de viktigste studiene er markert og kommentert. Litt påfallende er det at i redaktørens eget kapittel om benigne leverlesjoner er dette sparsomt omtalt, uten utheving av kjernereferanser. Gjennomsnittlig 5-10 viktige poenger oppsummerer hvert tema i kapitlene. En nettversjon av kapitlene er tilgjengelig og kan kjøpes separat, uten at undertegnede har gått inn for å vurdere denne. Dette gjelder også for de andre bøkene i serien.

Språket er lett og ledig, og teksten rikelig avbrutt av tabeller og faktabokser. Illustrasjonene er i de fleste tilfeller gode og representative. Leseren får en generell innsikt i anatomiske, fysiologiske og patogenetiske prinsipper for de ulike lidelsene. Diagnose og behandlingsalternativer skisseres, også de som kun drives på høyspesialiserte sentre, og informasjonsmengden er overkommelig. Boken synes således å egne seg vel så gjerne for etablerte kirurger som for utdanningskandidater.

\section{Kjetil Søreide}

Kirurgisk avdeling

Stavanger universitetssjukehus

\section{Lettlest lærebok i karkirurgi}

Beard JD, Gaines PA, red.

\section{Vascular and endovascular surgery}

A companion to specialist surgical practice.

4. utg. 392 s, tab, ill. Philadelphia, PA: Saunders Elsevier, 2009. Pris USD 128

ISBN 978-0-7020-3011-6

Vascular and endovascular surgery er en av utgivelsene i den britiske serien A companion to specialist surgical practice. Læreboken er myntet på spesialister og utdanningskandidater innen karkirurgi og intervensjonsradiologi, og hensikten er à gi en oversikt over det kunnskapsbaserte grunnlaget for karkirurgisk utredning og behandling.

Boken er innbundet og har 20 korte kapitler som dekker de fleste felter innen karkirurgi. Kapitlene er rikt illustrert med fotografier, røntgenbilder, tabeller og tekstbokser, og de avsluttes med en kort oppsummering.

Grunnlaget for dagens praksis i karkirurgi fremstilles på en konsis måte og inkluderer medikamentell behandling og åpen og endovaskulær kirurgi. Behandlingsanbefalinger gis etter grad av foreliggende evidens og er hovedsakelig basert på nyere litteratur. Leseren får en fortettet og rask oversikt over faget og forståelse for hva som er grundig og dessverre i noen tilfeller heller slett vitenskapelig fundert. En rekke forskjellige forfattere har bidratt, og kapitlene har et noe varierende nivå. I referanselistene er de viktigste artiklene uthevet for å stimulerer til videre lesing.

En 392 siders lærebok kan ikke erstatte større ensyklopediske verker, men formatet og utformingen gjør boken svært lesbar, og den kan med letthet leses fra perm til perm. Som det nevnes i forordet, har store lærebøker lang produksjonstid og står i fare for å være utdatert allerede ved publisering. Vascular and endovascular surgery oppdateres regelmessig og er etter 12 år allerede i fjerde utgave.

Boken er av interesse for alle som er involvert $\mathrm{i}$ behandling av arteriosklerotisk sykdom og ikke bare karkirurger og intervensjonsradiologer. Siden den er lettlest og har et begrenset antall sider, kan og bør den brukes aktivt.

\section{Morten Vetrhus}

Karkirurgisk seksjon

Kirurgisk avdeling

Stavanger universitetssjukehus

\section{Kompakt kompendium om kolorektalkirurgi}

Phillips RKS, red

\section{Colorectal surgery}

A companion to specialist surgical practice.

4. utg. 331 s, tab, ill. Philadelphia, PA: Saunders Elsevier 2009. Pris USD 128 ISBN 978-0-7020-3010-9

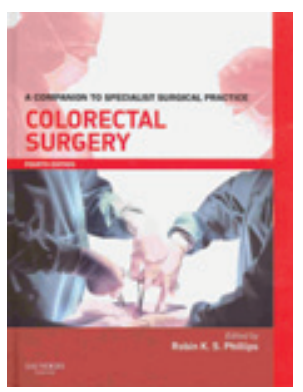

Dette er fjerde utgave av boken som omhandler benigne og maligne tilstander i colon, rectum og anus. Som i de andre bøkene i denne serien er også her kapitlene bygd opp på «evidence-based surgery»-prinsippet med litteraturgjennomgang og anbefalinger. Redaktøren erkjenner den økende bruk av multidisiplinære team i behandling av komplekse problemstillinger, og onkologer og gastroenterologer er medforfattere på enkelte kapitler. Forfatterne er nesten utelukkende britiske, og teksten er for så vidt preget av dette, med for eksempel undertitler som «endoscopy training in the UK», uten at innholdet mister sin allmenngyldighet. Egne kapitler om endoskopi, prosedyrer for behandling av rektal prolaps, og laparoskopi inkludert «fast-track/enhanced recovery» er nye i denne utgaven. I tillegg til kapitler om tykktarms- og endetarmskreft, samt analcancer, behandles også inflammatoriske tarmsykdommer (Crohns sykdom og ulcerøs kolitt) og divertikkelsykdom i egne kapitler. I det innledende kapitlet beskrives undersøkelse og fysiologiske målinger ved anorektale lidelser - her omtales både eksperimentelle målemetoder, metoder som er begrenset tilgjengelig (som defekografi) og mer utbredte metoder, som aktuell bruk av MR og ultralyd. Funksjonelle tarmlidelser behandles i to separate kapitler om henholdsvis kirurgisk og medisinsk behandling - det førstnevnte er i stor grad om behandlingsmetoder for rektal prolaps, mens sistnevnte er om irritabel tarm, obstipasjon og idiopatisk megacolon. Et eget kapittel er viet anorektale lidelser ved seksuelt overførbare sykdommer, inkludert hiv, syfilis og enkelte andre sykdommer som ikke er veldig vanlige i norsk praksis - her er det flere fargebilder som illustrasjoner. Verket er ikke altomfattende hva gjelder fagområdet koloproktologi, og selv om hemoroider og analfistler og -fissurer omtales, er også noen av disse dekket $\mathrm{i}$ boken Core topics in general and emergency surgery i samme serie. Enkelte aktuelle temaer savnes dekket, som laparoskopisk skylling som akuttbehandling i kapitlet om divertikulitt, men dette skyldes kanskje produksjonstiden fra manus til ferdig bok. Kapitlet om divertikulitt er for øvrig velskrevet. Boken inneholder veldig mye nyttig informasjon, og oppsettet er lett tilgjengelig både i språk og form, med bruk av tabeller og illustrasjoner og henvisning til referanser. Totalt sett er dette en bok som egner seg både for utdanningskandidater og etablerte kirurger.

Kjetil Søreide

Kirurgisk avdeling

Stavanger universitetssjukehus 